\title{
Implementasi Kebijakan Pengelolaan Sungai Di Kota Banjarmasin
}

\author{
Anjani $^{* 1}$, Muhammad Riduansyah Syafari ${ }^{2}$, Taufik Arbain ${ }^{3}$ \\ Program Studi Magister Administrasi Publik, Fakultas Ilmu Sosial dan Ilmu Politik, \\ Universitas Lambung Mangkurat
}

Korespondensi : anjaniani330@gmail.com

\begin{abstract}
Abstrak
Penelitian ini bertujuan untuk mengetahui Upaya Pemerintah Kota Banjarmasin dalam kebijakan pengelolaan sungai di Kota Banjarmasin dan mengetahui faktor-faktor yang mempengaruhi kebijakan pengelolaan sungai. Hasil penelitian menunjukkan bahwa upaya yang dilakukan masih belum optimal hal ini dikarenakan jumlah sungai dengan sumber daya manusia tidak berbanding lurus dengan anggaran yang tersedia, dukungan dari pihak-pihak yang terlibat kurang, Masyarakat acuh terkait kebijakan tersebut, dan pengetahuan mereka terkait pengelolaan sungai sangat sedikit.
\end{abstract}

Kata Kunci : Implementasi Kebijakan, Pengelolaan Sungai, Icon Kota

\begin{abstract}
This study aims to determine (1) the efforts of the Government of Banjarmasin City in river management policies in Banjarmasin City and (2) the factors that influence river management policies. This study uses a qualitative approach supported by two data collection techniques, namely interviews and documentation. The results show that the efforts have not been optimally conducted due to (a) the number of rivers and human resources are not directly proportional to the available budget, (b) lack of support from the parties involved, $(c)$ the community is ignoring the policy, and (d) they do not have enough knowledge of river management.
\end{abstract}

Keywords: Policy Implementation, River Management, City Icon

\section{PENDAHULUAN}

Penelitian ini didasarkan pada permasalahan kebijakan pengelolaan sungai di Kota Banjarmasin yang masih belum optimal, belum optimalnya ini diduga karena koordinasi dan komunikasi antara pemerintah kota Banjarmasin dengan masyarakat yang tinggal di Bantaran sungai masih kurang sehingga menyebabkan penanganan pengelolaan sungai mengalami berbagai permasalahan. Selama ini sangat nampak bahwa visi Walikota Banjarmasin mengarah kepada kebijakan pengelolaan sungai, hal ini sangat jelas dengan adanya kebijakan pengelolaan sungai yang berdasarkan pada Peraturan Daerah Kota Banjarmasin Nomor 15 Tahun 2016 tentang upaya peningkatan pengelolaan sungai yaitu meningkatnya pengelolaan sungai di Kota Banjarmasin dengan memanfaatkan potensi sungai secara optimal untuk kesejahteraan, kemakmuran rakyat dan kelestarian lingkungan hidup serta menjadikan sungai sebagai ciri khas daerah Kota Banjarmasin. Pengelolaan sungai berdasarkan Perda Kota Banjarmasin Nomor 15 tahun 2016 adalah upaya terpadu untuk merencanakan, mengembangkan, memanfaatkan dan memelihara kelestarian sungai. Langkah-langkah yang dilakukan Pemerintah Kota Banjarmasin untuk mencapai tujuan tersebut adalah dengan melakukan upaya-upaya untuk mempertahankan keberadaan sungai dan menjaga kelestarian sungai di Kota Banjarmasin.

Perkembangan manusia dan kebudayaan juga tidak bisa dilepaskan dari keberadaan sungai. (Zunairiyah:2018:26) Kota Banjarmasin di kenal sebagai Kota Seribu Sungai yaitu kota yang banyak 
dialiri sungai-sungai. Sungai merupakan bagian yang tidak bisa lepas dari kehidupan masyarakat baik dari segi ekonomi maupun pariwisata. Bukti keterkaitan sungai dengan manusia dan kebudayaannya tergambar dalam beberapa catatan sejarah (Zunairiyah:2018:26). Di lihat dari segi sejarah Masyarakat Kota Banjarmasin khususnya Suku Banjar suku asli Kota Banjarmasin sudah sejak lama mereka memanfaatkan sungai untuk kehidupan mereka seperti membangun pemukiman di bantaran sungai, perekonomian, perdagangan, dan tranfortasi. Inilah yang menjadikan sungai merupakan bagian yang sangat vital bagi kehidupan masyarakat Kota Banjarmasin itu sendiri.

Keberadaan pemukiman ini berakar pada motif sosial, ekonomi dan budaya sehingga mendorong manusia yang berada di tepi sungai tersebut untuk memanfaatkan sebesar-besarnya potensi yang ada di Bantaran Sungai tersebut (Basrawi dkk : 2017:2). Permasalahannya seiring dengan bertambah penduduk yang tinggal di pinggiran sungai akan menimbulkan berbagai permasalahan seperti sampah yang tidak terkendali, menghilangnya sungai-sungai dan beralihfungsinya sungai menjadi pemukiman penduduk. Sehingga jika tidak dikelola dengan baik maka sebutan Kota Banjarmasin sebagai kota seribu sungai akan menghilang.

Data Dinas Pekerjaan Umum dan Perumahan Rakyat Kota Banjarmasin pada tahun 2009 terdapat 102 sungai berdasarkan pada Surat Keputusan Walikota Banjarmasin Nomor 158 Tahun 2011 tentang Penetapan Sungai Sebagai Fasilitas Umum dan Aset Pemerintah Kota Banjarmasin. Pada tahun 2020 terjadi peningkatan jumlah sungai di Kota Banjarmasin yaitu sebanyak 190 sungai. Peningkatan jumlah sungai tersebut terjadi karena adanya pendataan ulang yang dilakukan oleh Pemerintah Kota Banjarmasin.

Hadirnya Peraturan Daerah Kota Banjarmasin Nomor 15 Tahun 2016, sebagai bentuk keseriusan pemerintah dalam Pengelolaan Sungai di Kota Banjarmasin. Hanya saja, sebagaimana yang dijelaskan pada paparan di atas, terjadi berbagai permasalahan yang mengiringi kebijakan pengelolaan sungai. Ekspektasi besar pada peraturan daerah tersebut bukan hanya sekedar berjalannya program-program pengelolaan sungai saja melainkan lebih dari itu yaitu Masyarakat Kota Banjarmasin mengerti bagaimana memanfaatkan sungai dan menjaga kelestarian lingkungan sungai di Kota Banjarmasin. Munculnya permasalahan sungai di Kota Banjarmasin merupakan permasalahan bersama yang harus dihadapi dengan melakukan kerjasama. Baik dari pemerintah, masyarakat maupun stakeholders yang terkait. Berdasarkan hal tersebut, maka yang menjadi fokus dalam penelitian ini adalah Impelemtasi kebijakan pengelolaan sungai di Kota Banjarmasin

\section{METODE}

Pendekatan penelitian yang digunakan dalam penelitian ini menggunakan pendekatan kualitatif. Lokasi yang dipilih untuk peneliti ini adalah kota Banjarmasin yaitu sungai yang berada di sekitaran kota Banjarmasin. Lokasi ini merupakan wilayah strategis kota Banjarmasin karena kota Banjarmasin dikenal sebagai kota seribu sungai artinya wilayah kota Banjarmasin banyak dialiri sungai. Jika sungai-sungai di Kota Banjarmasin mengalami penurunan jumlah dan kualitas maka sebutan kota Banjarmasin sebagai Kota Seribu Sungai juga akan menghilang. Selain itu, sungai juga merupakan sesuatu yang sangat vital bagi kehidupan masyarakat kota Banjarmasin itu sendiri baik untuk aktivitas perekonomian, pariwisata dan tranfortasi. Teknik Pengumpulan data secara umum ada 3 (tiga) yang sering digunakan dalam penelitian kualitatif, yaitu observasi, wawancara, dan dokumentasi. Analisis data yang digunakan pada penelitian ini menggunakan analisi data yang di kemukan oleh Miles dan Huberman (1984) dalam sugiono (2009:241) yaitu Analisis data adalah proses mencari dan menyusun secara sistematis data yang yang diperoleh dari hasil wawancara, catatan lapangan, bahan - bahan lain, sehingga dapat mudah dipahami, dan ditemuannya dapat di informasikan kepada orang lain. Analisis data dilakukan dengan mengorganisasikkan data, menjabarkannya ke dalam unit - unit, melakukan sintesa, menyusun ke dalam 
pola, memilih mana yang penting dan yang akan dipelajari dan membuat kesimpulan yang dapat diceritakan kepada orang lain di dukung oleh data dan informasi yang ada secara empiris, maka dapat ditarik kesimpulan mengenai upaya pemerintah kota Banjarmasin dalam mempertahankan icon kota seribu sungai dengan 4 (empat) tahapan yaitu pengumpulan data, reduksi data, penyajian data, dan verifikasi data.

\section{HASIL DAN PEMBAHASAN}

Adanya Kebijakan Pengelolaan sungai di Kota Banjarmasin dilatar belakangi kondisi wilayah Kota Banjarmasin yang bertanah rawa yang semakin tahun kualitas tanah dan kondisi sungai semakin menurun. Sehingga jika sungai di Kota Banjarmasin tidak di kelola dengan baik maka akan berdampak pada penataan kota dan icon kota seribu sungai seiring dengan berjalannya waktu akan menghilang. Adapun program yang sudah dilakukan oleh pemerintah kota Banjarmasin ialah sosialisasi terkait pentingnya pengelolaan sungai di kota Banjarmasin, pembuatan saluran siring,revitalisasi penataan bantaran sungai, pengerukan sungai, pendataan sungai, pembuatan signate, pembuatan dan pemasangan patok beton, serta melakukan pembebasan lahan. Banyaknya pihak yang terlibat dalam pengelolaan sungai kota Banjarmasin dinilai masih sangat kurang, pihak-pihak yang terlibat hanya pada bagian formulasi kebijakan (perumusan kebijakan) namun pada saat berjalannya kebijakan tersebut hanya sedikit yang ikut andil berpartisipasi untuk mensukseskan kebijakan tersebut.

Pada Peraturan Daerah Kota Banjarmasin Nomor 15 tahun 2016 tentang Upaya Peningkatan Pengelolaan Sungai di implementasikan dengan bertujuan melakukan perencanaan pengelolaan sungai, pengembangan potensi sungai baik dari ekonomi dan pariwisata, pemanfaatan sebagai transfortasi, serta pengelolaan keberlangsungan sungai di Kota Banjarmasin. Hadirnya Peraturan Daerah Kota Banjarmasin Nomor 15 Tahun 2016, sebagai bentuk keseriusan pemerintah dalam Pengelolaan Sungai di Kota Banjarmasin. Hanya saja, sebagaimana yang dijelaskan pada paparan di atas, terjadi berbagai permasalahan yang mengiringi kebijakan pengelolaan sungai yakni berkaitan dengan Pengembangan, Pemanfaatan dan Pengelolaan Sungai. Hal tersebut terjadi dapat dilihat dari sisi budaya masyarakat Kota Banjarmasin yang sudah sejak dulu bermukim di pinggiran sungai dan melakukan aktivitas perekonomian.

Model implementasi model jaringan dikembangkan oleh Walter Kickert, Erik-Hans Klin dan Joop Koopenjan dalam Nugroho (2014) menekankan bahwa implementasi kebijakan akan berhasil jika seluruh aktor-aktor yang terlibat dalam kebijakan melakukan kerjasama satu sama lain. Upaya Pemerintah Kota Dalam Mempertahankan Icon Kota Seribu Sungai Melalui Pelaksanaan Kebijakan Pengelolaan Sungai Di Kota Banjarmasin berdasarkan pada Peraturan Daerah Banjarmasin Nomor 15 tahun 2016 tentang Upaya Peningkatan Pengelolaan Sungai masih belum optimal dan berjalan sesuai dengan peraturan yang ada hal ini dikarenakan jumlah sungai dengan sumber daya manusia tidak berbanding lurus dengan anggaran yang tersedia serta dukungan dari pihak-pihak yang terlibat yang kurang sehingga menyebabkan kebijakan ini belum berjalan secara optimal. Masyarakat pinggiran sungai seakan acuh dan pengetahuan mereka terkait pengelolaan sungai sangat sedikit sekali bahkan mereka seakan tidak peduli terkait kebijakan tersebut.

Karakteristik budaya mempengaruhi dari adanya eksistensi kebijakan tersebut masyarakat Kota Banjarmasin masih beranggapan budaya tinggal di sungai merupakan budaya masyarakat Banjar sehingga semakin delimatisnya pemerintah Kota Banjarmasin melakukan implementasi kebijakan tersebut Masyarakat awam yang tinggal di sungai tidak mengetahui kebijakan tersebut adapun sosialisasi yang dilakukan pemerintah Kota Banjarmasin tidak menyeluruh walaupun dilaksanakan ke seluruh kecamatan di Kota Banjarmasin yang ikut hadir pada sosialisasi tersebut hanyalah tokoh-tokoh 
masyarakat yang ada sedangkan masyarakat biasa tidak dilibatkan dalam sosialisasi tersebut Affrian, $\mathrm{R}$. (2016). Peran dari komunitas yang ada di Kota Banjarmasin masih kurang. Sosialisasi yang dilakukan pemerintah kota banjarmasin tidak memberikan dampak apa-apa terkait pahamnya masyarakat terkait pengelolaan sungai sosialisasi tersebut hanya menyentuh pada aspek input dan output saja sedangkan pada aspek outcome dan feedback belum terlihat. Pengawasan terkait kebijakan ini masih sangat kurang dikarenakan jumlah sungai dengan sumber daya masyarakat tidak berbanding lurus dengan jumlah masyarakat Kota Banjarmasin yang tinggal dipinggiran yang banyak orangnya.

Oleh sebab itu, berdasarkan model implementasi jaringan diperlukan keterlibatan para aktor-aktor kebijakan aktor-aktor tersebut terdiri dari Pemerintah Kota Banjarmasin, Masyarakat Kota Banjarmasin, Swasta, Perguruan tinggi, kominitas-kominitas serta peran media untuk keberhasilan kebijakan tersebut. Peran mereka haruslah aktif bukan pasif seperti yang dijelaskan pada model jaringan. Pada pendekatan ini, koalisi dan/atau kesepakatan diantara aktor yang berada pada sentral jaringan yang menjadi penentu dari implementasi kebijakan dan keberhasilannya. Suksesnya kebijakan pengelolaan sungai karena semua unsur-unsur aktor-aktor yang saling bekerjasama satu sama lain. jika semua unsur tersebut bekerjasama maka kebijakan pengelolaan sungai akan berjalan sesuai dengan tujuan yang ada.

\section{Faktor-Faktor Pendukung dan Penghambat Mempengaruhi Upaya Pemerintah Kota dalam Mempertahankan Icon Kota Seribu Sungai}

Keberhasilan suatu kebijakan karena semua elemen aktor yang terlibat dalam kebijakan bisa bersinergis satu sama lain, sebaliknya kegagalan suatu kebijakan karena elemen-elemen aktor kebijakan tidak melakukan sinergisitas satu sama lain. Oleh karena itu perlu adanya sinergisitas dalam implementasi kebijakan. Ditemukan terdapat faktor-faktor yang mempengaruhi kebijakan pengelolaan sungai di Kota Banjarmasin. Faktor-faktor tersebut meliputi faktor pendukung keberhasilan kebijakan dan faktor penghambat keberhasilan kebijakan yang akan diuraikan sebagai berikut :

\section{Faktor Penghambat}

Pada saat mengimplementasikan sebuah kebijakan ada banyak hal yang mempengaruhi keberhasilan maupun kegagalan sebuah implementasi kebijakan. Termasuk kebijakan pengelolaan sungai di Kota Banjarmasin. Pada saat penerapan kebijakan tersebut tidak selalu berjalan dengan mulus termasuk pada kebijakan pengelolaan sungai. Berikut beberapa hambatan dalam pelaksanaan kebijakan pengelolaan sungai di Kota Banjarmasin ialah sebagai berikut:

\section{a) Budaya Masyarakat yang Terbiasa Tinggal di Tepian Sungai}

Budaya masyarakat yang terbiasa tinggal di tepian sungai ini tidak lepas dari yang namanya budaya sungai, hal itu dikarenakan Kota Banjarmasin merupakan kota seribu sungai dan karakteristik tanah di Kota Banjarmasin jenisnya tanah rawa. Pemukiman sungai sudah lama ada masyarakat pinggiran sungai rata-rata mereka yang tinggal dipinggiran sungai tanah yang mereka miliki ialah tanah warisan dari kakek atau orangtuanya. Selain mereka tinggal dipinggiran sungai mereka juga melakukan aktivitas perekonomian seperti mencari nafkah, transfortasi dan aktivitas pribadi seperti mandi, mencuci dan buang air besar. Aktivitas-aktivitas yang dilakukan oleh masyarakat pinggiran sungai ini akan berdampak pada keberlangsungan sungai di Banjarmsin dan menimbulkan masalah-masalah seperti sampah dan pendangkalan sungai.

\section{b) Kurangnya Koordinasi dan Kerjasama antara Pemerintah dan Masyarakat Kota Banjarmasin}


Koordinasi dan kerjasama merupakan bagian penting dalam pelaksanaan kebijakan pengelolaan sungai di Kota Banjarmasin. Koordinasi dan Kerjasama yang dilakukan masih kurang sehingga terjadi permasalahan dalam penerapannya. Sosialisasi diberikan oleh pemerintah Kota Banjarmasin masih tidak menyeluruh hanya orang-orang tertentu seperti tokoh masyarakat atau pak RT yang ikut sosialisasi sehingga pengetahuan masyarakat terkait kebijakan pengelolaana sungai sangat minim bahkan tidak tau sama sekali adanya kebijakan tersebut.

Keterlibatan semua pihak pada pelaksanaan kebijakan ini sangat penting bagaimana tidak kalau misalkan hanya pemerintah saja bergerak namun masyarakat tidak setuju kebijakan tersebut tidak bisa jalan sehingga sangat perlu yang namanya koordinasi dan kerjasama serta pemahaman tentang pentingnya pengelolaan sungai tersebut.

Pada saat pelaksanaan kebijakan pengawasan sangat diperlukan untuk memastikan apakah kebijakan tersebut berjalan sesuai dengan aturan yang ada. Namun, pada pelaksanaannya karenanya kurang koordinasi dan kerjasama pengawasan yang dilakukan masih kurang.

Pengawasan pada kebijakan pengelolaan sungai ini masih sangat kurang karena sumber daya sedikit sedangkan jumlah sungai banyak dan pemukiman di pinggiran sungai banyak, sehingga terjadi keteledoran dalam Pengawasan terhadap bangunan yang ada. pada aturan yang ada seharusnya sudah bangunan yang terbakar akibat kebakaran tidak boleh dibangun. Statusnya kalau diperda status qou kalau sudah runtuh tidak boleh dibangun kembali. Seiring dengan berjalannya waktu harus dikembalikan lagi sebagaimana mestinya. Namun, pada faktannya masyarakatnya tetap membangun.

Aspek Koordinasi dan kerjasama sangat penting pada kebijakan ini jika koordinasi dan kerjasama kurang maka kebijakan tersebut akan berjalan kurang optimal. Begitupula pada kebijakan pengelolaan sungai ini kebijakan yang dijalankan masih belum optimal dan masih kurangnya pengetahuan masyarakat terkait pengelolaan sungai dan pengawasan yang kurang dikarenakan kurangnya kerjasama dan koordinasi antara pemerintah kota Banjarmasin dengan pihak-pihak yang terlibat menyebabkan kebijakan ini masih belum optimal dan menjadi kendala pada penerapannya.

\section{c) Sumber Daya Manusia yang belum memadai}

Sumber Daya Manusia merupakan salah satu faktor penting dalam kebijakan pengelolaan sungai. Kendala yang di hadapi dalam kebijakan pengelolaan sungai ialah Sumber Daya Manusia yang belum memadai. Sehingga kurangnya sumber daya manusia menjadi kendala dalam penerapan kebijakan pengelolaan sungai, SDM yang terbatas dengan jumlah sungai yang banyak tidak berbanding lurus.

\section{d) Anggaran Terbatas}

Anggaran adalah rencana keuangan yang disusun secara sistematis yang meliputi semua aktivitas pengelolaan sungai di Kota Banjarmasin. Anggaran merupakan hal penting dalam kebijakan pengelolaan sungai. Namun, anggaran terbatas menjadi kendala dalam kebijakan pengelolaan sungai. Anggaran untuk pengelolaan sungai di kota Banjarmasin itu cukup besar dan itupun masih belum cukup padahal sungai di Kota Banjarmasin itu banyak. Sehingga pengelolaan sungai di Kota Banjarmasin terbatas dan harus ada prioritas yang mana terlebih dahulu diutamakan dalam pengelolaan sungai di Kota Banjarmasin.

\section{Faktor Pendukung}

\section{Kerjasama dan Koordinasi}


Koordinasi dan kerjasama merupakan hal penting dalam hal pelaksanaan kebijakan pada pengelolaan kebijakan pengelolaan sungai di Kota Banjarmasin koordinasi dan kerjasama antara Pemerintah dan Masyarakat masih kurang, hal ini perlu adanya peningkatan kembali kerjasama dan koordinasi kepada pihak masyarakat kota Banjarmasin. Keterlibatan semua pihak pada pelaksanaan kebijakan ini sangat penting bagaimana tidak kalau misalkan hanya pemerintah saja bergerak namun masyarakat tidak setuju kebijakan tersebut tidak bisa jalan sehingga sangat perlu yang namanya koordinasi dan kerjasama serta pemahaman tentang pentingnya pengelolaan sungai tersebut.

\section{Sumber Daya Manusia yang memadai}

Sumber Daya Manusia merupakan salah satu faktor penting dalam kebijakan pengelolaan sungai di Kota Banjarmasin. Apabila Sumber Daya Manusia kurang maka implementasi kebijakan akan belum maksimal sebaliknya apakah Sumber Daya Manusia cukup maka implementasi kebijakan berjalan secara optimal. Kendala yang di hadapi dalam kebijakan pengelolaan sungai di Kota Banjarmasin ialah Sumber Daya Manusia yang belum memadai. Sehingga sumberdaya yang memadai akan mendukung keberhasilan dari kebijakan pemelihraan sungai.

\section{Anggaran yang cukup}

Anggaran adalah rencana keuangan yang disusun secara sistematis yang meliputi semua aktivitas pengelolaan sungai di Kota Banjarmasin. Anggaran merupakan penting dalam kebijakan pengelolaan sungai. Namun, anggaran terbatas menjadi kendala dalam kebijakan pengelolaan sungai. Maka dari itu adanya anggaran cukup akan menjadi fakto pendukung dari keberhasilan kebijakan tersebut. Anggaran untuk pengelolaan sungai di kota Banjarmasin itu cukup besar dan itupun masih belum cukup padahal sungai di Kota Banjarmasin itu banyak.

Masih banyak Pekerjaan Rumah yang belum terselesaikan dalam kebijakan pengelolaan sungai. Terkait pengelolaan sungai kalau merujuk keperaturan yang ada sungai harus bebas seperti jalan tol kalau untuk pengalirannya. karena fungsi sungai sebagai saluran utama ibaratnya seperti jalan tidak boleh ada gangguan. Cuma karakteristik budaya yang beda anggaran yang ada jadi secara parsial dan untuk pengelolaan sungai seharusnya pengelolaannya setiap tahun karena mereka barang bergerak ada aliran air yang itu memang harus pengelolaan secara rutinitas.

Pada Faktor-Faktor yang mempengaruhi kebijakan pengelolaan sungai hal yang sangat penting dalam kebijakan tersebut adalah semua aktor-aktor merasa memiliki peran dan terlibat dalam penerapan kebijakan tersebut tidak bisa hanya pada satu aktor atau beberapa aktor saja seluruh elemen dalam kebijakan harus ikut andil bagian demi mensukseskan kebijakan tersebut. Kurangnya koordinasi dan aktor-aktor kebijakan hanya memiliki peran sedikit saja menjadi hambatan penerapan kebijakan ini. Mengandalkan sumber daya manusia dan anggaran dari pemerintah saja tidak cukup bagaimana tidak jika sungai di Kota Banjarmasin sudah dilakukan kegiatan pengelolaan masyarakat tidak mau menjaga maka akan kembali lagi rusak dan tidak terawat. Selain itu, alangkah baiknya program kebijakan tersebut mengikutsertakan semua elemen masyarakat, sebagaimana sudah disebutkan di atas.

\section{KESIMPULAN}

1. Upaya Peningkatan Pengelolaan Sungai masih belum optimal dan berjalan sesuai dengan peraturan yang ada hal ini dikarenakan jumlah sungai dengan sumber daya manusia tidak berbanding lurus dengan anggaran yang tersedia serta dukungan dari pihak-pihak yang terlibat kurang sehingga menyebabkan kebijakan ini belum berjalan secara optimal. Karakteristik budaya mempengaruhi dari adanya eksistensi kebijakan tersebut masyarakat Kota Banjarmasin masih beranggapan budaya tinggal di sungai merupakan budaya masyarakat Banjar sehingga semakin delimatisnya pemerintah Kota 
Banjarmasin melakukan implementasi kebijakan tersebut. Terkait pengelolaan implementasi kebijakan ini hanya menyentuh ranah input, proses dan output saja, sedangkan pada aspek outcome dan feedback belum terlihat. Selain itu, alangkah baiknya program kebijakan tersebut mengikutsertakan semua elemen masyarakat, sebagaimana sudah disebutkan di atas.

2. Faktor penghambat dalam upaya pemerintah kota Banjarmasin dalam pengelolaan sungai ialah budaya masyarakat kota Banjarmasin, kurangnya koordinasi dan kerja sama, sumber daya manusia yang belum memadai, dan anggaran terbatasan. Sedangkan faktor pendukung dalam dalam upaya pemerintah kota Banjarmasin dalam pengelolaan sungai ialah kerja sama dan koordinasi, sumber daya manusia yang memadai, serta anggaran yang cukup.

\section{SARAN}

Beberapa Penjelasan dan Kesimpulan di atas, maka untuk mencapai tujuan dalam program kebijakan pengelolaan sungai di Kota Banjarmasin perlu :

1. Menambah sumber daya manusia yang selama ini mempunyai keterbatasan personil dalam pelaksanaan dan mengawasi kebijakan Peraturan Walikota tentang pengelolaan sungai. Tujuannya agar dalam pelaksanaan kebijakan tersebut bisa efektif dan maksimal serta seimbang antara jumlah sungai yang ada di Kota Banjarmasin dengan jumlah pegawai yang melaksanakan kebijakan tersebut melalui Peraturan Daerah ini.

2. Menambah kerjasama Pemerintah, Masyarakat Kota Banjarmasin, Pihak Swasta, Organisasi Kemasyarakatan, LSM, Komunitas, para akademisi dan media sama-sama melakukan koordinasi dan kerjasama sehingga kebijakan tersebut bisa berjalan dengan maksimal. Seluruh elemen dan aktor kebijakan harus ikut andil demi tercapainya kebijakan tersebut. Mereka sebagai pelaksana, memberikan edukasi terkait pentingnya pengelolaan sungai dan ikut andil mengawasi kebijakan tersebut.

\section{DAFTAR PUSTAKA}

[1] Affrian, R. (2016). Implementasi Kebijakan Pemungutan Retribusi Pelayanan Parkir Di Pasar Induk Kota Amuntai Kabupaten Hulu Sungai Utara. As-Siyasah: Jurnal Ilmu Sosial Dan Ilmu Politik, 1(1).

[2] Basrawi, Diana Viyanti, Yusriani Sapta Dewi. (2017) Pengaruh Kemampuan Pengelolaan Tata Ruang Pemukiman Bantaran Sungai dan Gender Terhadap New Invironmental Paradigm (NEP). Jurnal Green Griwth dan Manajemen Lingkungan p (1-20) ( Vol. 6 No.1

[3] Maryam, Neneng Siti. (2016) Mewujudkan Good Governance Melalui Pelayanan Publik. Jurnal Ilmu Politik dan Komunikasi p (1-17) (Vol.1 Juni)

[4] Nasution. (2003). Metode Penelitian Naturalistik Kualitatif. Bandung: Tarsito.

[5] Nugroho, Riant (2014). Public Policy. Jakarta: Elex Media Komputindo.

[6] Peraturan Daerah Kota Banjarmasin Nomor 15 tahun 2016 tentang Upaya Peningkatan Pengelolaan Sungai. 
[7] Peraturan Pemerintah Peraturan Pemerintah Nomor 38 Tahun 2011 Tentang Pengelolaan Sungai.

[8] Sugiono. (2009). Metode Penelitian Kuantitatif Kuantitif \& $R \& D$. Bandung: ALFABETA.

[9] Sugiyono, (2017). Metode Penelitian Kebijakan(Pendekatan Kuantitatif dan Kualitatif, Kombinasi R \& D dan Penelitian Evaluasi). Yogjakarta : Alfabeta.

[10] Zunariyah, Siti. (2018). Upaya Membangun Kemitraan dalam Pengelolaan Sungai yang Berwawasan Lingkungan.Jurnal Sosiologi p (25-46) Vol.2 No. 1. 